\author{
Sustinere \\ Journal of Environment and Sustainability \\ Volume 5 Number 1 (2021) 35-48 \\ Print ISSN: 2549-1245 Online ISSN: 2549-1253 \\ Website: https://sustinerejes.com E-mail: sustinere.jes@iain-surakarta.ac.id
}

\title{
RESEARCH PAPER \\ Big data analytics of sustainable ecotourism development in Bromo Tengger Semeru National Park
}

\author{
Joshi Maharani Wibowo*, Sri Muljaningsih, Dias Satria \\ Dept of Economics, Faculty Economics and Business, Universitas Brawijaya, Malang, Indonesia \\ Article history: \\ Received 11 September 2020 | Accepted 21 April 2021 | Available online 30 April 2021
}

\begin{abstract}
Bromo Tengger Semeru National Park (BTSNP) are designated as the 10 new Bali of Indonesia. As a protected area, BTSNP has unique ecotourism characteristics that distinguish it from other ecotourism destinations. This study seeks to examine the appropriateness of BTSNP sustainable development-based ecotourism through the Sustainable Livelihoods Approach (SLA) approach. This study used TripAdvisor reviews related to BTSNP in 2019 as the main data. The data were analyzed using a qualitative approach. The results of this study revealed the extent to which the process of developing BTSNP ecotourism on the basis of sustainable development as observed from economic, tourism, socio-cultural, and environmental aspects. The results of this study are expected to be considerations for policymaking to develop tourism that pays attention to the environment by not imposing BTSNP boundaries as protected areas for conservation.
\end{abstract}

Keywords: Sustainable Livelihoods Approach (SLA); BTSNP; Big Data; Ecotourism

\section{Introduction}

Bromo Tengger Semeru National Park (BTSNP) are one of the three National Parks designated as the 10 New Bali along with the Labuan Bajo National Parks (NPKLB) and Wakatobi National Parks (NPW) (Ministry of Tourism, 2018). BTSNP manages seven zones namely the core zone, jungle zone, intensive use zone, rehabilitation zone, religious use zone, traditional use zone, and special zone (BBTNBTS, 2019). BTSNP ecotourism's development lies in the intensive use zone with its natural attractions such as Mount Bromo sea of sand, Mount Bromo crater, and Mahameru Peak. Based on Law Number 5 of 1990 concerning Conservation of Biological Natural Resources and their Ecosystems, an obligation to succeed in conservation and tourism is an economic value obtained in BTSNP management as a protected area. Consequently, there are certain restrictions BTSNP cannot impose in the tourism sector.

National parks such as BTSNP can economically produce both market and non-marketbased goods (Hayati \& Wakka, 2016). Tourism in protected areas such as BTSNP, does not only provide positive externalities of market-based economic value to local communities but also providing negative externalities such as waste and environmental quality degradation (Andrawina et al., 2019; Sunaryo, 2013). In its practice, tourism activities in BTSNP

${ }^{*}$ Corresponding author. E-mail: jhosiyosi@gmail.com DOI: https://doi.org/10.22515/sustinere.jes.v5i1.134 
were defying the mandate of Law Number 10 of 2009, which was followed up through Government Regulation Number 50 of 2011 concerning Master Plan of National Tourism Development (RIPPARNAS). BPS - Statistics Indonesia (2018) stated there are many tourism destinations directly disposing of their waste into the environment. East Java province ranks $8^{\text {th }}$ out of all provinces in Indonesia and ranks first in Java since $81.12 \%$ of tourism destinations in East Java dispose waste straight into the environment. Only $18.18 \%$ of them process their waste before being disposed of. Certainly, the BTSNP tourism area which is located in East Java also has a significant contribution to this.

Big data analytics uses social media to provide data since technology has an essential role in sustainable development, especially in Indonesia. Ministry of Tourism (2018) in their Strategic Plan at 2018-2019 (Rencana Strategis 2018-2019) elaborated that digital technology, especially social media, plays an important role as the keys to tourism digitalization in Indonesia. Nowadays, tourists vacating to certain tourism destinations provide reviews regarding the destination through their favorite social media such as Facebook, Instagram, Twitter, TripAdvisor, YouTube, and others. They write or make a video to make reviews of their experience in various aspects such as destination locations and accessibility, facilities and infrastructure, and environment. This kind of social media data can be analyzed using specific methods depending on research needs.

Cusick et al. (2010) in their paper "Representations of ecotourism in the Hawaiian Islands: A content analysis of local" conducted similar research yet used local media such as newspapers and magazines as research data. The study uncovered that ecotourism in the economic sector provided economic benefits, but environmentally, ecotourism caused significant degradation and changed its environmental culture (damaging environmental balance). In this modern day, the use of written media-based data has been abandoned because there is an increased a zero-waste trend that makes digital-based data like TripAdvisor review very valuable. This study aims to explore the appropriate tourism activities in BTSNP based on the social ecotourism perspective using the Sustainable Livelihoods Approach (SLA). The results of this study are expected to contribute to the development of tourism destinations that integrate tourism, economy, society, and environment in its execution (Hayati \& Wakka, 2016; Ministry of Tourism, 2018; Sunaryo, 2013).

\section{Literature Review}

\subsection{Ecotourism}

Tourism is a temporary travel activity carried out by individuals/groups for great experience without harming environmental, social, cultural, and scientific balance (Utomo et al., 2020). Based on the economic viewpoint, tourism is one of the potential sectors to increase national income since the tourism sector has a significant influence on government spending and income, increasing job vacancy and tax expenditure (Kweka et al., 2003; Nandi, 2008). Barbosa et al. (2010) in their research state that the tourism sector has a high opportunity to provide an economic activity (increasing small-business) and provide a positive experience for tourists in the long term.

Tourism activity can be grouped into several types such as cultural tourism, marine tourism, tourism, ecotourism, and edutourism (Utomo et al., 2020). Ecotourism is a tourism activity based on sustainable development concept to develop a nature-based tourism destination (Lee \& Moscardo, 2005). Ecotourism destinations usually located in rural areas with natural and cultural 
richness providing tourists experience and a better understanding of the natural history of the environment. This is the reason why tourism management always carefully develops conservation and economic potential with minimum investment to make sure local communities gain economic benefits without harming their natural and cultural capitals (Adriana et al., 2016; Ocampo et al., 2018). Developing an ecotourism destination is considered developing with nature-based tourism with environmental responsibility (Sheng Hshiung Tsaur et al., 2006).

Sustainable ecotourism activity usually has educational tourism activity to provide tourists with environmental and cultural insight, also to encourage them to preserve this natural environment and pass it down to future generations (Adriana et al., 2016; Lee \& Moscardo, 2005). Hence, ecotourism destination is not only an economic opportunity but also a challenge for the sustainable development of Indonesia (Li, 2004). If tourism management fails to develop tourism areas, especially ecotourism, the tourism destination will destruct environmental sustainability due to the environmentally unfriendly tourism activity (Lonn et al., 2018; Sheng Hshiung Tsaur et al., 2006).

\subsection{Sustainable Livelihoods Approach (SLA)}

The tourism sector is the most dynamic sector that can be developed based on sustainable concepts aiming to increase economic, social, and environmental growth. Tourism destinations based on sustainable development usually just prioritized the economic sector instead of balancing it with the social environment sector (Amir et al., 2015). Many researchers try to avoid such conditions by measuring the balance of tourism and sustainable development to create a mutually beneficial relationship among economic, social, and environmental interests (Tao \& Wall, 2009). Measuring sustainable tourism can be done objectively. Measuring sustainable tourism from an economic view should be carried out subjectively and objectively making the research result does not look suspicious and invalid (Tsaur et al., 2006).

One of the measuring tools for measuring sustainable development in tourism sectors is the Sustainable Livelihoods Approach (SLA). SLA can measure social phenomena focused on individuals or communities toward phenomena based on their ability, capital, and activity to survive. Based on the economic and environmental viewpoint, SLA is a community approach paradigm to fulfill their basic needs while trying to minimize environmental degradation, performing environment rehabilitation, and paying attention to social equity between the environment and local community needs. There are five main capitals based on the SLA concept, they are natural capital, physical capital, social capital, financial capital, and human capital (Kumar et al., 2019). In the long-term, the result of SLA data analysis not only can support sustainable development in the economic sector but also in social and environmental sectors (Tao \& Wall, 2009).

\section{Methodology}

This research was conducted in BTSNP, East Java Province from August to November 2019. The study used primary and secondary data. Primary data were collected through interviews, focus group discussions (FGD), observation, and documentation. Selected interviewees were determined using purposive sampling. Meanwhile, secondary data were obtained through relevant agencies such as the Great Bromo Tengger Semeru National Parks (BBTNBTS). The reviews from TripAdvisor related to BTNSP in 2019 were obtained through Bank Indonesia, Malang Town. According to Bank Indonesia in Malang Town, the TripAdvisor reviews 
data related to BTSNP in 2019 was obtained using a method called data mining through Python Programing Language. From the TripAdvisor review data related to BTSNP in 2019, there were 564 reviews (388 reviews from 39 countries and 176 reviews could not be identified) as shown in table 1.

Table 1. Data of the Number of Accounts that Writing a Review for BTSNP in TripAdvisor and their Origin Country in 2019

\begin{tabular}{lclclc}
\hline \multicolumn{1}{c}{ Country } & $\begin{array}{c}\text { Total } \\
\text { Review }\end{array}$ & \multicolumn{1}{c}{ Country } & $\begin{array}{c}\text { Total } \\
\text { Review }\end{array}$ & Country & $\begin{array}{c}\text { Total } \\
\text { Review }\end{array}$ \\
\hline Indonesia & 97 & Thailand & 7 & Ireland & 2 \\
Netherland & 39 & Canada & 5 & Poland & 2 \\
Singapore & 39 & Denmark & 5 & Chile & 1 \\
United Kingdom & 27 & Korea & 5 & Czech Republic & 1 \\
France & 22 & Spain & 5 & Estonia & 1 \\
Malaysia & 20 & China & 4 & Finland & 1 \\
Australia & 16 & Switzerland & 4 & Myanmar & 1 \\
United State & 16 & Austria & 3 & New Zealand & 1 \\
Germany & 12 & Japan & 3 & Oman & 1 \\
Italy & 11 & Mexico & 3 & Portugal & 1 \\
India & 8 & Philippines & 3 & Slovenia & 1 \\
Taiwan & 8 & Vietnam & 3 & South America & 1 \\
Belgium & 7 & Colombia & 2 & Ireland & 2 \\
\hline
\end{tabular}

This study also obtained the primary data using focus group discussions (FGD), observation, and documentation to support the TripAdvisor reviews data. The data collected from FGD was obtained by discussing sustainable tourism in BTSNP with the relevant stakeholders (informant). The informants of FGD are presented in table 2.

Table 2. Informant Data for FGD

\begin{tabular}{llcl}
\hline No & \multicolumn{1}{c}{ Group } & Total & \multicolumn{1}{c}{ Location } \\
\hline 1 & $\begin{array}{l}\text { Local Communities as BTSNP Business } \\
\text { Actors }\end{array}$ & 2 & BTSNP \\
2 & $\begin{array}{l}\text { BBTNBTS party } \\
3\end{array}$ & 3 & $\begin{array}{l}\text { BBTNBTS Office and BI Meeting } \\
\text { Room Malang } \\
\text { BTSNP and BI Meeting Room } \\
\text { Community }\end{array}$ \\
\hline
\end{tabular}

This study used a phenomenological approach, which was analyzed through sentiment analysis. The analysis process of this data used applications such as NVIVO 11 pro and Microsoft Excel to process the analysis data according to research needs. Using the NVIVO 11 Pro, the reviews related to BTSNP in TripAdvisor in 2019 were mapped into five main categories according to the SLA concept (natural capital, physical capital, social capital, financial capital, and human capital). After that, every data in every SLA category was analyzed using sentiment analysis and mapped again according to the sentiment category. Sentiment analysis is a coding process to categorize TripAdvisor reviews into three categories of negative, positive, and neutral categories (Harish Kumar et al., 2019).

Being mapped using sentiment categories, the results/output of data was analyzed using primary data based on the qualitative method. After the analysis using qualitative analysis, the 
results were processed into a word cloud, word tree, and treemaps to make them easier to describe (Bandur, 2016). This description explained the meaning, concept, definitions, characteristics, metaphor, symbol, and description related to BTSNP sustainable ecotourism (Bappeda Kabupaten Banyuwangi, 2019).

\section{Result and Discussion}

\subsection{Natural Capital}

Natural capital is the most visible capital in BTSNP ecotourism. It becomes BTSNP's main attraction. The Indonesian government has issued various regulations on the exploitation of natural tourism, which can be done in protected areas such as BTSNP (Isnan, 2016). As shown in figure 1, the natural capital as the main attraction of BTSNP that TripAdvisor reviewers often visit were Mount Bromo (62.04\%), Penanjakan 1 (6.75\%), Teletabies Hill (5.61\%), Mount Semeru (5.48\%), Ranupani (5.35\%), Cinta Hill (4.33\%), Kingkong Hill (2.93\%), and Mount Batok (2.93\%). These eight places are open to tourists and located in the intensive use zone. The most prominent activity related to natural capital were sunrise (6.82\%) of Penanjakan 1 and Bromo volcano crater (crater 3.35\% and volcano 3.59\%).

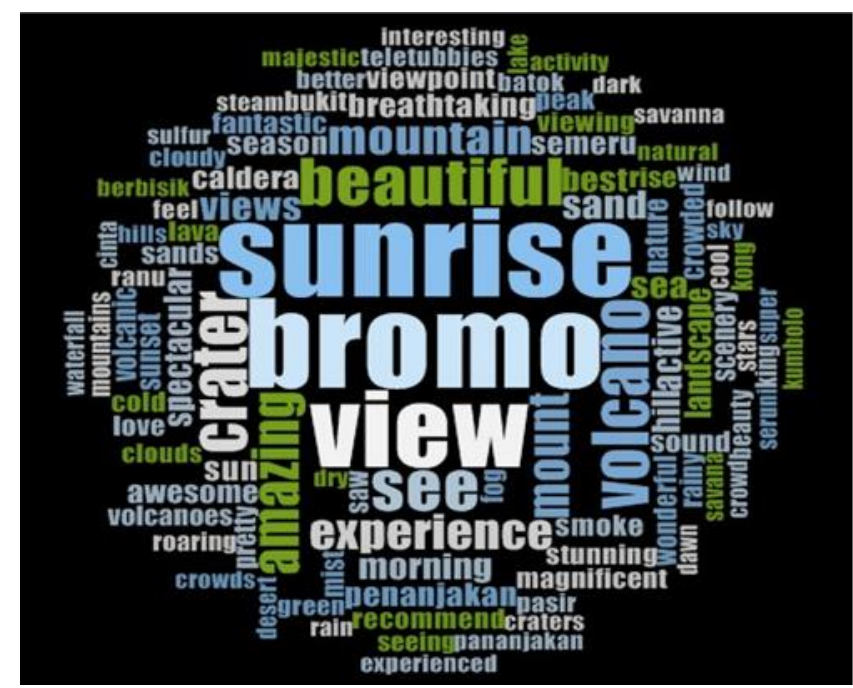

Figure 1. Natural Capital Word Cloud (Primary Data, 2020)

Based on 708 coding results related to natural capital in BTSNP (573 positives, 31 negatives, and 105 neutral) we found two main problems in BTSNP as indicated by negative sentiment namely weather and crowd. Some negative sentiments related to weather indicated that the weather was unfavorable so that the main attractions such as sunrise becomes invisible, especially during when the rainy season. The gate to Bromo Crater was also closed. The crowd shows a high negative interest in BTSNP because it exceeds the capacity. BTSNP has a capacity of 1,467 people/per day at three sunrise points (Penanjakan 1, Kedaluh Hill, and Cinta Hill) (BBTNBTS, 2018a). Based on BTSNP visit data in 2017, the average visit was 1774 people for each day (BBTNBTS, 2018b). This amount has exceeded BTSNP capacity, even if we saw them based on the everyday visit. Peak season in July or December usually is the time when BTSNP visitors exceed daily capacity. The non-stop exploitation of BTSNP natural capital for tourism activities had negative impacts such as tourism waste and degradation of BTSNP natural capital. 


\subsection{Physical Capital}

Physical capital in BTSNP has 481 codings resulted from 183 positive sentiments, 98 negative sentiments, and 200 neutral sentiments with 'jeeps' as the most dominant words as seen on the word cloud in Figure 2. Jeep (7.48\%) is the main vehicle for tourism activities in BTSNP. Jeep or Toyota Landcruiser is the main vehicle that was determined by BBTNBTS to reduce accidents in BTSNP. Particularly, Mount Bromo sea of sand has geographical uniqueness, as when raining, potholes in the sea of sand (jeglongan) will move around and its location cannot be determined. Thus, it requires adequate skills to ensure the safety of BTSNP tourists.
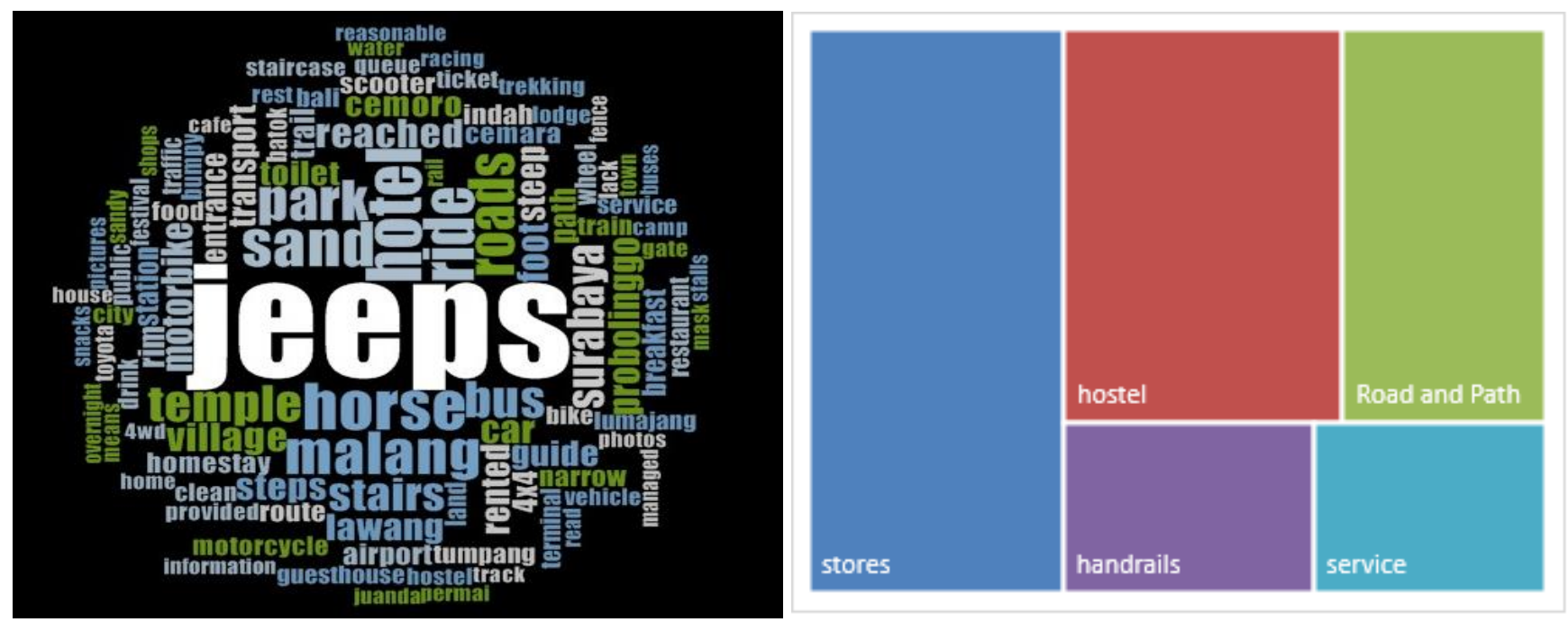

Figure 2. Physical Capital Word Cloud (left) and TreeMap (right) (Primary Data, 2020)

"By Foot" was the second choice for visitors when visiting BTSNP. This is because Jeep rentals are too expensive and other reasons related to the environment are also mentioned. Because at certain times, the Jeep in BTSNP exceed the determined capacity (270 jeeps each day) especially the peak season in the morning may cause traffic in certain areas such as Penanjakan 1 and Cinta Hill (BBTNBTS, 2018b). Another popular alternative vehicle is a motorbike. The visitors are allowed to ride their private motorbikes into BTSNP. Many local tourists rode their bike in the Mount Bromo sea of sand. Tourists can also rent a motorbike in BTSNP and many tourists reviewing motorbike activities as one of the main attractions in BTSNP because riding a motorbike in the Mount Bromo sea of sand provides a unique experience for tourists.

There are four most frequently mentioned main infrastructures besides transportation from the tourist reviews on TripAdvisor. First, stores (21.90\%) are booths of goods and services providers at Mount Bromo sea of sand. They had a quite high level of negative sentiment because goods and services offered are 2-3x out of market price. Second, hostels (16.71\%) refer to lodging at Cemoro Lawang area which also has a lot of negative sentiments because the prices are too expensive but services offered are not comparable. The lodging is dirty, has no bathroom inside, and unfriendly local people. Third, road and path $(12.25 \%)$ related to BTSNP road, in which at certain areas still not safe enough to pass. Roads from Malang or Lumajang District are considered to be quite extreme despite being an exceptional experience for tourists with special interests (adventure). Finally, handrails (6.48\%) refer to security-related infrastructure (safety 
fences) in many areas both at the sunrise point and at the top of the Bromo crater. The handrail at the mentioned area is considered not to provide security as it should.

Based on the four problems of infrastructure mentioned, roads and paths have their own characteristics. Because out of the four problems, this problem cannot be solved by BBTNBTS alone. It must be intervened and assisted by parties from the regional government, especially four districts (Malang, Pasuruan, Probolinggo, and Lumajang) as well as the Governor of East Java Province. Roads are infrastructure related to accessibility to BTSNP. There are roads within BBTNBTS jurisdiction and other roads within local government jurisdiction. Roads at those areas must be fixed to facilitate access to BTSNP without risking visitor's safety. Many roads to BTSNP are in disaster-prone area, especially from Malang District and Lumajang District.

\subsection{Social Capital}

Social capital in BTSNP based on 341 coding results (124 positives, 84 negatives, and 133 neutrals) can be divided into two main topics namely social capital related to behavior and social capital related to the culture as BTSNP main attractions (Figure 3). Reviews related to public behavior towards tourists are mostly negative because many local people consider tourists as their gold mining. While in the category related to cultural attractiveness, many are neutral or positive, especially at the 'Yadnya Kasada' ceremony.
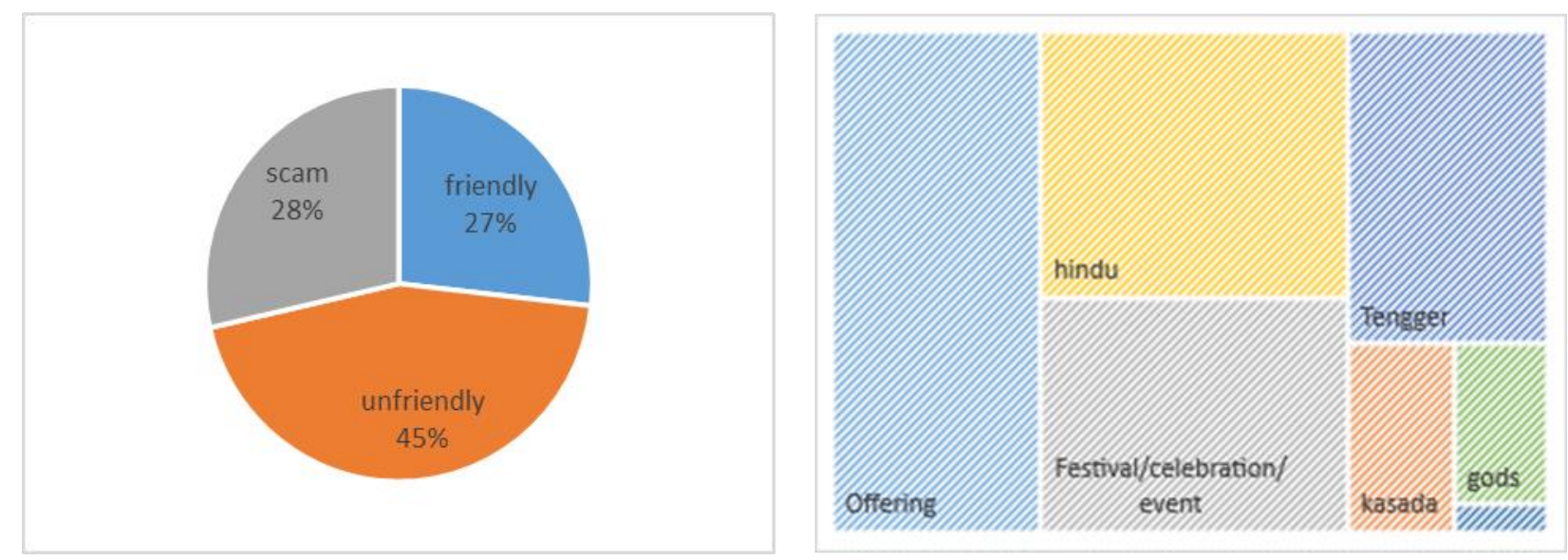

Figure 3. BTSNP Community Behaviour (left) and Cultural Attraction TreeMap (right) (Primary Data, 2020)

Based on Figure 3 on the left side, there are two negative sentiments related to community behavior namely unfriendliness and scam. These were indicated by words of horses and jeeps that appeared frequently. Horse (7.20\%) shows that communities owning horses to be offered to tourists (a horse community). A horse community often does a scamming by chasing visitors who come in jeeps and forcing them to use their riding horse services to climb Bromo crater or just walking around the sea of sand at a high price.

Jeep (5.05\%) is the second most frequent word that appeared after horses directed to the Jeep community in the BTSNP area. Usually, the Local Jeep Community provides tourists false information before they enter BTSNP such as 'you must enter the area in a Jeep', or 'it is impossible for walking or riding private motorbikes in the Mount Bromo sea of sand'. So many of them stopping visitors that came using private vehicle and forced them renting the Jeeps. This case often happens in the Tumpang rest area or gas station at Bromo highway (Probolinggo entrance through 
Tongas). Local communities such as BTSNP business Actors often show unfriendly behavior towards other business actors that come from outside the area, such as the Jeep community from Malang and Surabaya. They made unofficial regulations based on local people's tradition (without any formal legal basis such as laws or government regulations) to reduce competitors from outside BTSNP. BTSNP cultural attraction is shown in Figure 3 on the right side. Social capital such as BTSNP tourist attraction is a culture owned by the Tengger community who live in 17 Tengger villages around BTSNP (BBTNBTS, 2018b). According to the Tengger community who are Hindu, the offering is mandatory. Some of these cultures have been adapted into BTSNP visitor's activities. One of them is offering, which is a word that shows an Edelweiss Flower offering into Mount Bromo crater which is the Tengger community's culture to respect their ancestors.

The second word commonly appeared at the Tengger community's religious festival is 'Kasodo'. 'Kasodo' stands for 'Yadnya Kasada', one of annual international festival in BTSNP based Indonesia tourism branding called 'Eksotika Bromo' (cultural festival in Bromo). Besides 'Yadnya Kasada', BTSNP also has many impressive religious ceremonies similar to 'Yadnya Kasada' such as 'Karo' and 'Unan-Unan'. The are many other traditional ceremonies based on their purposes like people life cycle, such as birth (sayutceremony, ticker puser, tugel kuncung), marriage (walagara ceremony), death (entas-entas, etc.), religious ceremonies related to the agricultural cycle, house building, and natural phenomena such as leliwet and barikan (BBTNBTS, 2018b). Such activities are a social capital potential owned by BTSNP. They should be held more frequently by the Tenggers community since they are still unknown by most BTSNP tourists.

\subsection{Financial Capital}

The main topic related to financial capital usually mentioned about the expensive entrance, due to domestic and foreign tourist entrance tickets differences. Figure 4. showing some big words 'pay' (5.99\%), 'price' (4.70\%), 'entrance' (4.40\%), and 'ticket' (1.40\%). Many of these word have negative sentiments. The interview results with business actors in BTSNP revealed that there were a lot of negative statements related to expensive entrance tickets, especially BTSNP entrance tickets for foreign tourists, that 10 times more expensive than domestic tourists.

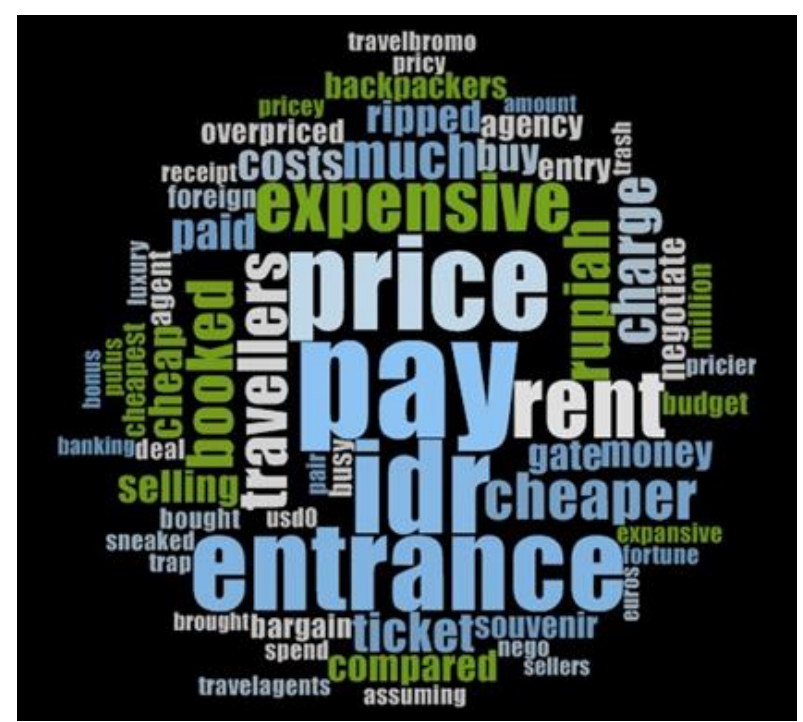

Figure 4. Financial Capital Word Cloud (Primary Data, 2020) 
BTSNP entrance ticket is determined by the Ministry of Environment and Forestry through Law Number 12 of 2014 regarding Types and Rates of Non-Tax State Revenues applied at the Ministry of Forestry. BTSNP is a protected area that has the main obligation to conserve the existing biodiversity around the area, which makes the tourism activity is only an added economic value obtained. Currently, BTSNP uses a dual pricing system, so there are differences in ticket prices for domestic and foreign tourists. Dual pricing is often used in tourism or industry (usually mining or petroleum goods base) to suppress externalities negative issue related to the environment due to economic activity (Yang et al., 2016). This limitation cannot be imposed on BTSNP and other national parks that become the 10 new Bali, such as NPKLB and NPW.

Based on 144 coding results related to financial capital in BTSNP (38 positives, 48 negatives, and 58 neutrals). Negative sentiment dominates this category. One of them is shown at word 'cheaper' which appears at positive and negative sentiments. In positive sentiment 'cheap' means the ticket is cheap. However, a negative sentiment, cheap means they need some cheaper options. That is why many tourists (especially foreigners) tried to enter BTSNP illegally (not through the entrance and paying for tickets). Ticket booth and entrance at BTSNP have loose security. BBTNBTS rarely sweeps the other path except for the main gate due to their lack human resources.

\subsection{Human Capital}

Based on the treemap in Figure 5, human capital in BTSNP mainly works in six areas such as tour guides, drivers, stableman, seller/renter (goods and services), lodging workers, and administration (registration to climb to Mount Semeru at Ranupani Resort BBTNBTS). Guides, drivers, and stableman are the three most popular types of jobs in BTSNP. Becoming a stableman is the only job that entirely absorbing human resources from the Tengger community and enclave village. While the five other types of work such as guides and administration, not only absorbing human resources from the Tengger community and enclave village but also workers from outside with required capacities such as from Malang, Surabaya, Pasuruan, Probolinggo, and Lumajang.

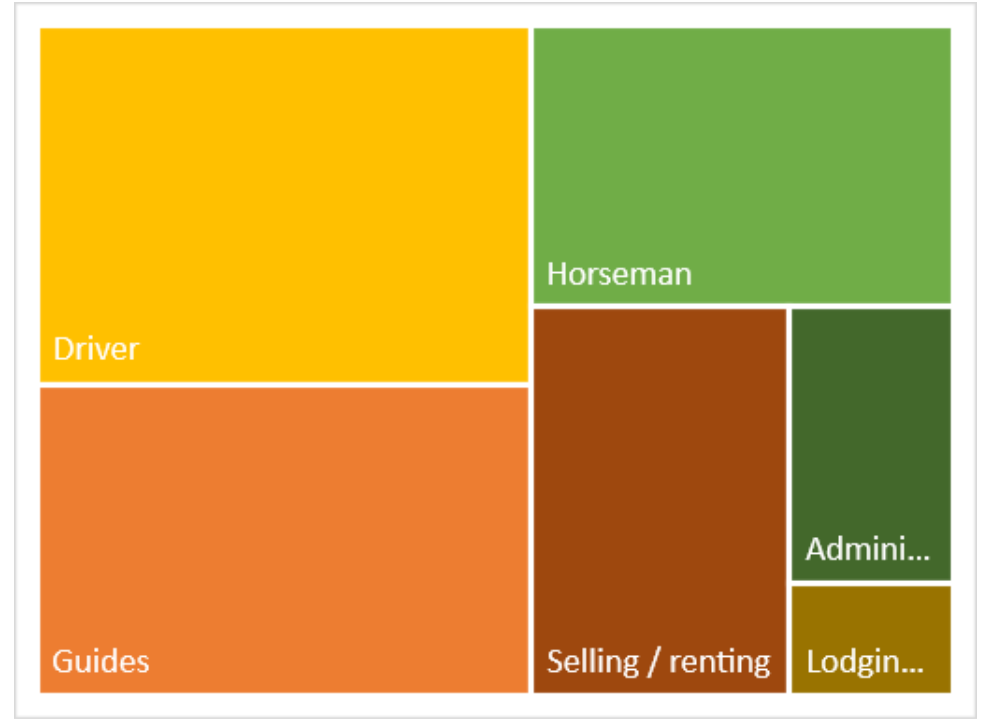

Figure 5. Human Capital Treemap (Primary Data, 2020) 
Human capital has 118 coding results (51 positives, 29 negatives, and 38 neutrals). Positive sentiments appear to be relatively frequent due to the dominance of guides from outside of Tengger and enclave villages. Hence, the impression obtained was positive because they gave professional services. Guides from local people usually are found at the Mount Semeru climbing area. Negative sentiments related to human capital are mostly found in the Mount Bromo area, especially those who work as drivers, stablemen, and shopkeeper (goods and services). Many Indonesian people have low education levels including local people from Tengger and the enclave, many of them cannot read or write (Saputro \& Ardhiansyah, 2018). Communication within BTSNP ecotourism area is not only limited by language barriers but also education level, lacking /less training, and their habits in performing conversations. For local people, it might sound familiar, but for tourists, it sounds rude/unfriendly.

Education for BTSNP local community is like a luxury good. Most of them merely have education up to elementary school level. Infrastructure and facilities equivalent to junior high and high school are often placed outside their village area and must struggle with more sacrifice. Also, although infrastructure and facilities targeted for junior and senior high school education are built in that village area, the community has low interest to pursue higher education. It became a problem. Because even though infrastructures and facilities have been fulfilled, they cannot provide maximum benefits to the community (BBTNBTS, 2018b).

\subsection{SLA towards BTSNP Sustainable Development}

In this study, SLA shows the role of the five SLA capitals (financial, human, natural, social, and physical) towards BTSNP in sustainable development. It also means that not only community welfare is seen, but also changing environmental conditions due to ecotourism activities in BTSNP. Based on Figure 6, financial capital shows the most influences of SLA with 0.15. Financial capital in BTSNP ecotourism area is obtained through sales on tickets, food, drinks, snacks, and warm clothing. Financial capital is also obtained through the rental of jeeps, motorbikes, horses, lodging, and toilets. Sources of obtaining financial capital in BTSNP are quite diverse. Goods and services providers set quite high prices. However, this high price is not solely determined because of scamming behavior by the community. Based on interview data, several business Actors (usually local people) mentioned BTSNP have the low infrastructure, and its difficult for providing goods and services at basic prices (wholesale places). They need to bring these goods and services from nearby cities to BTSNP, especially food, drinks, snacks, and warm clothing.

Natural capital which is visibly abundant, the fact, only has a value of 0.04 in SLA. A unique potential or attraction regarding BTSNP natural capital largely determines the visit rate that will later create other related tourism sectors in BTSNP (Yuniarti et al., 2018). Unfortunately, natural capital in BTSNP cannot be fully utilized, because there is a limit that cannot be imposed for the development of BTSNP tourism based on General Director Decree KSDAE with No.SK.381/KSDAE/SET/KSA.0/9/2016 dated on 2016, September $30^{\text {th }}$ as a limit that (BBTNBTS, $2019)$. Only about $1,143.61$ ha out of $1,193.43$ ha $(2.37 \%)$ of BTSNP area used as the main attraction in the tourism sector.

Human capital, surprisingly, has a value of 0.10 , the second-highest after financial capital. Human capital in BTSNP started being dominated by domestic communities outside BTSNP. That became a dilemma itself. The positive impact of BTSNP wasn't received by the Tengger and the enclave village community ( 85 villages) but received by the people from outside 
(four districts and Surabaya City). This result was not expected based on the social aspects of ecotourism sustainable development. Developing sustainable ecotourism based on social aspect need to be identified and organized by involving stakeholders especially local communities in order to produce maximal benefit. Human capital in protected areas such as BTSNP with low education level does not care about legality like Natural Tourism exploitation permit (IPPA) or law procedure which can actually support their economic levels. Many small businesses like selling or renting goods carried out by local communities are still mostly illegal because many stakeholders from local communities do not have the IPPA. Mudhofir, Nugroho, and Soedomo (2018) stated that until 2017, there were only 153 small business owner have IPPA in the protected area like BTSNP.

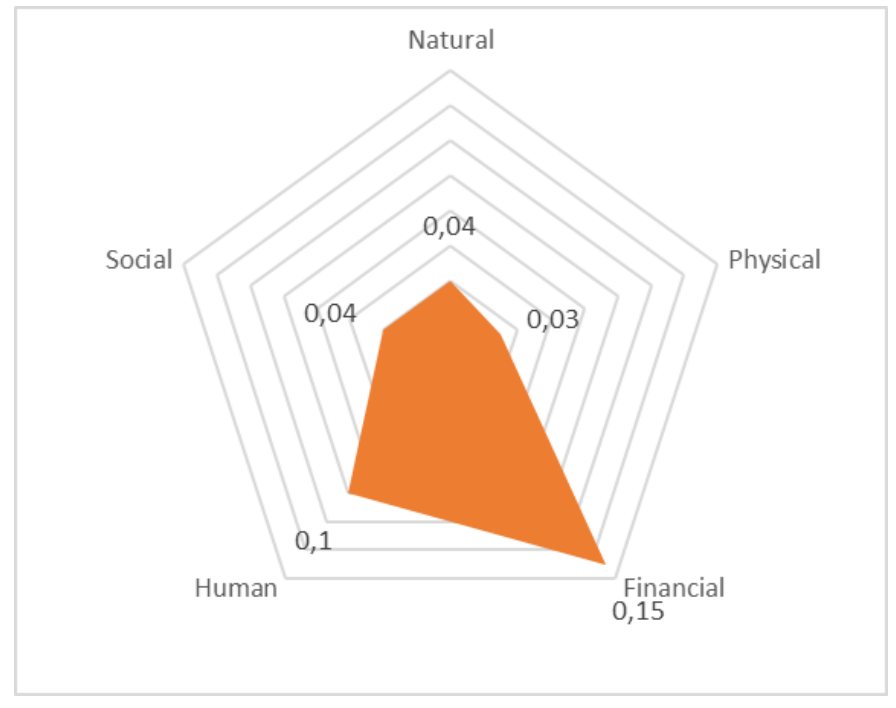

Figure 6. BTSNP based on SLA

Social capital has the same value as natural capital with a score of 0.04 . However, this low value is due to different causes. Social capital in BTSNP is valued low because of many negative behaviors that are unfriendly and scamming. Besides, the social capital of cultural attraction in BTSNP has not been widely introduced and known by tourists. A cultural performance like the Yadnya Kasada ceremony is not only seen merely that way, it also mentioned that Yadnya Kasada is sacredly exhibited to tourists. Tengger community in living their lives embraces the five life values known as Panca Setya. At present, it remains unknown Tengger community's cultural boundaries which can be exhibited as cultural attractions in BTSNP.

Physical capital has the lowest value of 0.03. Infrastructure in the BTSNP area is still very minimal. The lack of water sources and clean water in the Mount Bromo sea of the sand area makes goods and services in BTSNP very expensive (Haris et al., 2017). Thus, good and service providers in BTSNP must buy water for selling food, drinks, and visitor's sanitation. Consequently, it makes them cost higher. Also, road infrastructure is not good enough for large numbers of tourists to pass, especially through Malang and Lumajang Districts due to the lack of road infrastructure and extreme geographical conditions. BTSNP is far from public services such as airports, trains, and ports. The only public transportation to BTSNP can be found at the Probolinggo terminal, a minivan (bison) with a yellow plate and costs affordable. The natural geographical condition of BTSNP, which is still fairly original, made it more challenging to develop BTSNP infrastructure, even 
though BTSNP has a high selling value for adventure tourism. Unfortunately, the market for this type of tourism is still minimal and only demande

The unevenness of sustainable tourism development in BTSNP, which is still dominated by the financial capital category, shows that BTSNP is currently experiencing negative growth. It can be concluded that most of the local communitiy's financial modal obtained from tourism activity is not used to developing ecotourism in BTSNP. Many local people around the BTSNP use that money for personal use such as to buy another paddy field nearby. This condition will delay the development of sustainable tourism development in BTSNP that covers social, environmental, and economic sectors. This situation can worsen as many local people just try to benefit from tourism activity without developing or maintaining biodiversity In the surrounding area. The local people's mindset who only thinks about the tourism activity as their gold miner eventually will destroy the environment around the BTSNP due to the overexploitation.

This study proposed several recommendations to create a suitable policy to develop sustainable ecotourism in BTSNP as follows. First, it is necessary to create a policy related to longterm sustainable ecotourism for BTSNP covering the economy, environment, social, and dan tourism sectors. Second, the government needs to approach local people by creating the informal and formal training program. The formal program should be created to increase the human capital capacity for utilizing the natural, social, financial, and physical capital in BTSNP tourism activity. Meanwhile, the informal program is created to affecting and changing the local people mindset and behavior towards the tourism activity. Thus, the tourism development in BTSNP can create a harmonious, sustainable ecotourism activity that integrating local people, tourist, and other related stakeholders.

\section{Conclusion}

The development of ecotourism in BTSNP currently does not provide positive externalities based on maximum sustainable development. Communities, business actors, and tourists still do not understand that BTSNP is a protected area. There are certain restrictions where BTSNP cannot be fully exploited for tourism activity. On the other hand,, BTSNP is more used by business actors from outside of BTSNP than those of local communities. This situation creates economic and cultural gaps between local communities, business actors from outside of BTSNP, tourists, and the government.

The government's role is absolutely needed in BTSNP to formally mediate this problem. Further, traditional law in BTSNP must be reviewed for its suitability for tourism activities through formal law in order to create harmony among stakeholders. In addition, training and funds support is certainly needed. However, what is most needed is training for the local community's mindset change with training in related skills. Mindset/behavior referred here refer to how local community and BTSNP business actors understand that BTSNP ecotourism is an activity that seeks to create solutions of environmentally-based integrated sustainable development not only as a tourism activity.

\section{Acknowledgment}

The authors express their heartfelt gratitude to Bank Indonesia in Malang City as the data main contributor and funding for supporting this research. The authors also express their appreciation 
to BBTNBTS as an instantiation that contributed secondary data related to BTSNP condition, as well as all interviewees of this research.

\section{References}

AdrianaTisca, I., Istrat, N., Dumitrescu, C. D., \& Cornu, G. (2016). Management of Sustainable Development in Ecotourism. Case Study Romania. Procedia Economics and Finance, 39(November 2015), 427-432. https://doi.org/10.1016/s2212-5671(16)30344-6

Amir, A. F., Ghapar, A. A., Jamal, S. A., \& Ahmad, K. N. (2015). Sustainable Tourism Development: A Study on Community Resilience for Rural Tourism in Malaysia. Procedia - Social and Behavioral Sciences, 168, 116-122. https://doi.org/https://doi.org/10.1016/j.sbspro.2014.10.217

Andrawina, K. E., Zulfikri, A., Roberth, T., \& Maranatha, R. (2019). Women and Wastes: Study on the participation of housewives on plastic waste management in Kecandran, Salatiga , Indonesia. 3(3), 199212. https://doi.org/10.22515/sustinere.jes.v3i3.90

Bandur, A. (2016). Penelitian Kualitatif: Metodologi, Desain, dan Teknik Analisis Data Dengan Nvivo 11 Plus (Jatmiko (ed.); 1st ed.). Mitra Wacana Media.

Bappeda Kabupaten Banyuwangi. (2019). Smart Tourism: Laporan Akhir Kajian Pengembangan Smart Tourism untuk Mendorong Pembangunan yang Inklusif di Kabupaten Banyuwangi.

Barbosa, L. G. M., Oliveira, C. T. F. de, \& Rezende, C. (2010). Competitiveness of tourist destinations: the study of 65 key destinations for the development of regional tourism. Revista de Administração Pública, 44(5), 1067-1095.

BBTNBTS. (2018a). Daya Dukung BTSNP. Balai Besar Taman Nasional Bromo, Tengger, dan Semeru.

BBTNBTS. (2018b). Rencana Strategis Ekowisata BTSNP. Balai Besar Taman Nasional Bromo, Tengger, dan Semeru.

BBTNBTS. (2019). Taman Nasional Bromo, Tengger, Semeru. Balai Besar Taman Nasional Bromo, Tengger, dan Semeru.

Cusick, J., Mcclure, B., \& Cox, L. (2010). Representations of ecotourism in the Hawaiian Islands: A content analysis of local media. Journal of Ecotourism, 9(1), 21-35. https://doi.org/doi:10.1080/14724040902803412

Haris, M., Soekmadi, R., \& Arifin, H. S. (2017). Potensi daya tarik ekowisata suaka margasatwa bukit Batu kabupaten bengkalis Provinsi Riau. Jurnal Penelitian Sosial Dan Ekonomi Kehutanan, 14(1), 39-56. https://doi.org/http://dx.doi.org/10.20886/jpse.2017.14.1.39-56

Hayati, N., \& Wakka, A. K. (2016). Valuasi Ekonomi Manfaat Air Di Taman Nasional Bantimurung Bulusaraung, Sulawesi Selatan. Jurnal Penelitian Sosial Dan Ekonomi Kehutanan, 13(1), 47-61. https://doi.org/doi:10.20886/jsek.2016.13.1.47-61

Isnan, W. (2016). Harga Optimaltiket Masuk Wisata Alam Bantimurung, Sulawesi Selatan. Jurnal Penelitian Sosial Dan Ekonomi Kehutanan, 13(3), 155-163. https://doi.org/doi:10.20886/jsek.2016.13.3.155163

Kumar, H., Pandey, B. W., \& Anand, S. (2019). Analyzing the Impacts of forest Ecosystem Services on Livelihood Security and Sustainability: A Case Study of Jim Corbett National Park in Uttarakhand. International Journal of Geoheritage and Parks, 7(2), 45-55. https://doi.org/https://doi.org/10.1016/j.ijgeop.2019.05.003

Kumar, Harish, Pandey, B. W., \& Anand, S. (2019). Analyzing the Impacts of forest Ecosystem Services on Livelihood Security and Sustainability: A Case Study of Jim Corbett National Park in Uttarakhand. International Journal of Geoheritage and Parks, 7(2), 45-55. https://doi.org/10.1016/j.ijgeop.2019.05.003

Kweka, J., Morrissey, O., \& Blake, A. (2003). The economic potential of tourism in Tanzania. Journal of International Development, 15(3), 335-351.

Lee, W. H., \& Moscardo, G. (2005). Understanding the impact of ecotourism resort experiences on tourists' environmental attitudes and behavioural intentions. Journal of Sustainable Tourism, 13(6), 546-565. https://doi.org/10.1080/09669580508668581

Li, W. (2004). Environmental management indicators for ecotourism in China's nature reserves: A case 
study in Tianmushan Nature Reserve. Tourism Management, 25(5), 559-564. https://doi.org/10.1016/j.tourman.2003.06.001

Lonn, P., Mizoue, N., Ota, T., Kajisa, T., \& Yoshida, S. (2018). Evaluating the Contribution of Community-based Ecotourism (CBET) to Household Income and Livelihood Changes: A Case Study of the Chambok CBET Program in Cambodia. Ecological Economics, 151(October 2017), 62-69. https://doi.org/10.1016/j.ecolecon.2018.04.036

Ministry of Tourism. (2018). Rencana Strategis 2018-2019.

Nandi. (2008). Pariwisata dan Pengembangan Sumberdaya Manusia. 8(1).

Ocampo, L., Ebisa, J. A., Ombe, J., \& Geen Escoto, M. (2018). Sustainable ecotourism indicators with fuzzy Delphi method - A Philippine perspective. Ecological Indicators, 93(November 2017), 874-888. https://doi.org/10.1016/j.ecolind.2018.05.060

Saputro, B., \& Ardhiansyah, F. (2018). Preliminary research on environmental literacy and conservation toward eco - tourism through the community learning centre. 2(3), 144-155. https://doi.org/10.22515/sustinere.jes.v2i3.44

Sunaryo, B. (2013). Kebijakan Pembangunan Destinasi Pariwisata: Konsep dan Aplikasinya di Indonesia (Edisi Pert). Gava Media.

Tao, T. C. H., \& Wall, G. (2009). Tourism as a sustainable livelihood strategy. Tourism Management, 30(1), 90-98. https://doi.org/https://doi.org/10.1016/j.tourman.2008.03.009

Tsaur, S. H., Lin, Y. C., \& Lin, J. H. (2006). Evaluating ecotourism sustainability from the integrated perspective of resource, community and tourism. Tourism Management, 27(4), 640-653. https://doi.org/https://doi.org/10.1016/j.tourman.2005.02.006

Tsaur, Sheng Hshiung, Lin, Y. C., \& Lin, J. H. (2006). Evaluating ecotourism sustainability from the integrated perspective of resource, community and tourism. Tourism Management, 27(4), 640-653. https://doi.org/10.1016/j.tourman.2005.02.006

Utomo, F. N., Supyandi, D., \& Syamsiyah, N. (2020). Economic value of Bandung Orchid Forest, West Java. Sustinere, 4(2), 79-93.

Yang, Y., Zeng, M., Xue, S., Wang, J., \& Li, Y. (2016). Unifying the "dual-track" pricing mechanism for coal in China: Policy description, influences, and suggestions for government and generation enterprises. $\begin{array}{llll}\text { Resource Conservation } & \text { Recycling, } & \text { 402-415. }\end{array}$ https://doi.org/http://dx.doi.org/10.1016/j.resconrec.2016.04.004

Yuniarti, E., Soekmadi, R., Arifin, H. S., \& Noorachmat, B. P. (2018). Analisis Potensi Ekowisata Heart Of Borneo Di Taman Nasional Betung Kerihun Dan Danau Sentarum Kabupaten Kapuas Hulu. Journal of Natural Resources and Environmental Management, 8(1), 44-54. https://doi.org/10.29244/jpsl.8.1.44-54 